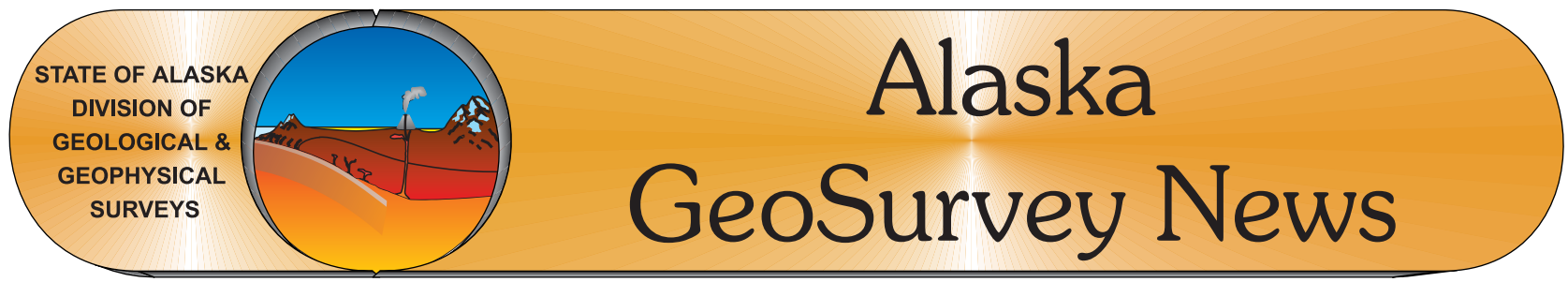

http://www.dggs.dnr.state.ak.us

Vol. 13, No. 1, February 2010

\title{
EVIDENCE FOR LATE WISCONSINAN OUTBURST FLOODS IN THE TOK-TANACROSS BASIN, UPPER TANANA RIVER VALLEY, EAST-CENTRAL ALASKA
}

\author{
Trent D. Hubbard ${ }^{1}$ and Richard D. Reger ${ }^{2}$
}

\section{INTRODUCTION}

In 2006 the Alaska Division of Geological \& Geophysical Surveys began an investigation of the geology and geologic hazards in the proposed natural-gas pipeline corridor through the upper Tanana River valley (Combellick, 2006; Solie and Burns, 2007). Much of this work has involved reconnaissance geologic mapping along a 12-mi-wide (19.3-km-wide) corridor centered along the Alaska Highway between Delta Junction and the Canada border. While mapping in the Tanacross Quadrangle (fig. 1) in 2008, we investigated the Tok fan to better understand its development during the last major glaciation. Like Foster (1970) and Carrara (2006), we recognize older and younger parts of the broad, low-gradient fan. The western

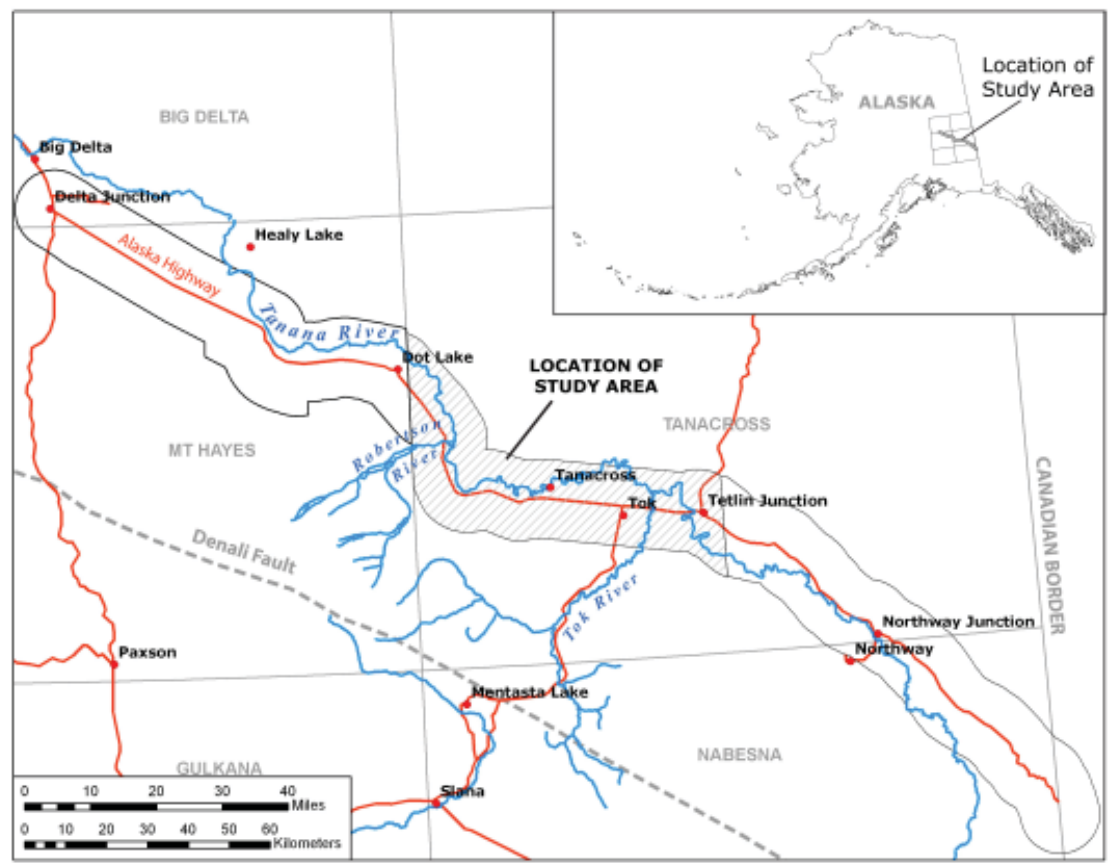

Figure 1. Location of study area in Tanacross Quadrangle, Alaska. half is Donnelly (marine oxygen-isotope stage 2) in age and the inset eastern half is Holocene. Our discussion here focuses on development of the older fan surface.

\section{TOK FAN MORPHOLOGY AND MATERIAL CHARACTERISTICS}

The Tok fan, which occupies most of the Tok-Tanacross basin, was created by streams flowing from the Tok River valley (fig. 2). Although described as an alluvial fan (Williams, 1970, p. 43), this feature lacks properties typically attributed to alluvial fans, including high-value radial slopes, limited radial length, and planoconvex cross profile (Blair and McPherson, 1994, p. 454). The Tok fan is up to $\sim 24 \mathrm{mi}(\sim 39 \mathrm{~km})$ wide, has radii that vary in length from $\sim 8$ to $\sim 26 \mathrm{mi}$ ( $\sim 13$ to $\sim 42 \mathrm{~km}$ ), and the fan surface slopes from $\sim 7.6$ to $\sim 21 \mathrm{ft} / \mathrm{mi}(\sim 1.4$ to $\sim 4 \mathrm{~m} / \mathrm{km})$.

On the higher, older fan surface, a series of 3.3- to 10-ft-deep (1- to 3-m-deep) fingerlike surface channels containing sand fills up to $\sim 1 \mathrm{ft}(0.3 \mathrm{~m})$ thick, which are locally cross bedded, radiate from the mouth of the Tok River valley toward the fan margins. We measured loess covers that average $\sim 6$ in thick ( $15 \mathrm{~cm}$ thick) but range from 2 to 22 in $(5$ to $56 \mathrm{~cm})$ on the older fan surface. According to John Burnham (07/25/08, oral commun.), the cover of silt on the Tok fan east of the Glenn Highway Tok Cutoff is generally $<12$ in $(<30 \mathrm{~cm})$ thick, although locally the silt is up to $10 \mathrm{ft}(3 \mathrm{~m})$ thick, and the thickness of silt increases close to the Tanana River. A typical post-Donnelly soil profile is developed on this surface (fig. 3).

\footnotetext{
${ }^{1}$ Alaska Division of Geological \& Geophysical Surveys, 3354 College Rd., Fairbanks Alaska 99709-3707 Email for T.D. Hubbard: trent.hubbard@alaska.gov

${ }^{2}$ Reger's Geologic Consulting; P.O. Box 3326; Soldotna, AK 99669
} 


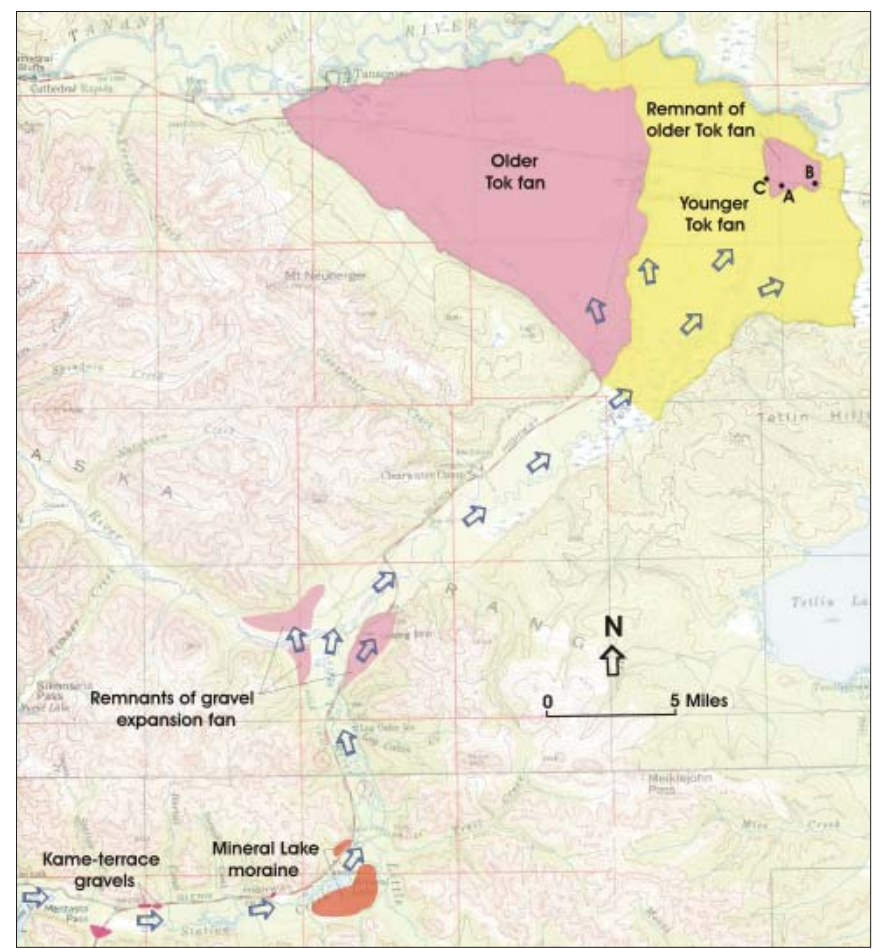

Figure 2. Course of outburst floods (blue arrows) from Mentasta Pass to Tok fan during Donnelly glaciation relative to locations of large boulders in northeastern Tok fan (localities A-C). Landforms in upper Tok River and Little River valleys interpreted from Foster (1970) and Richter (1976).

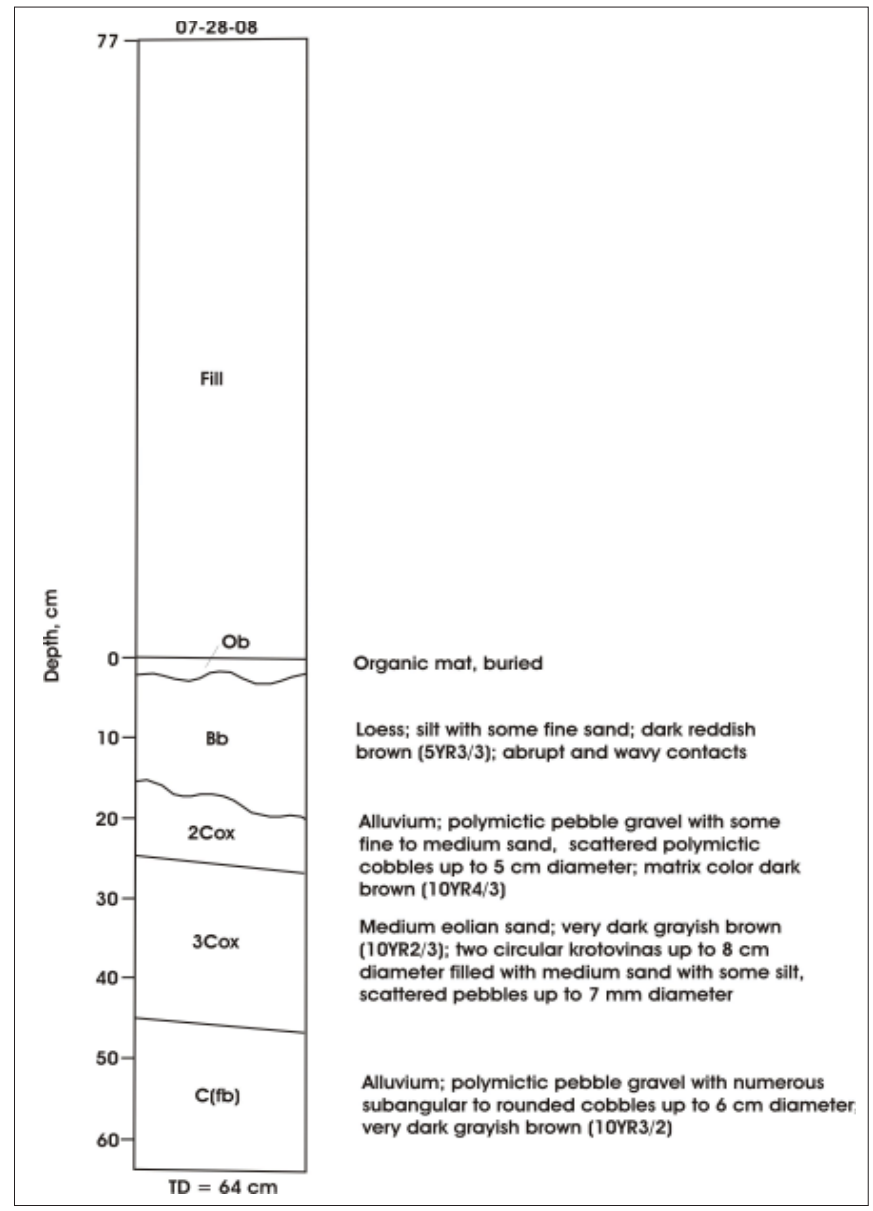

Examination of numerous gravel pits in the older, higher surface of the Tok fan indicates that this feature primarily is composed of massive pebble gravels with some medium to coarse sand, numerous cobbles, and rare boulders up to 12 in $(\sim 30 \mathrm{~cm})$ diameter. Clasts, which are generally subrounded to rounded and polymictic, generally increase in size toward the apex of the fan. In gravel exposures, Alaska Range lithologies dominate. Holmes (1965, table 4) segregated the lithologies of 100 clasts at five sites on the Tok fan into several classes: dense basalt (48-60 percent, average 54.2 percent), granitic (4-21 percent, average 12.6 percent), vesicular basalt (4-20 percent, average 10.8 percent), quartzite-quartz (3-14 percent, average 7.6 percent), andesite ( $0-9$ percent, average 3.8 percent), gneiss-schist ( $0-7$ percent, average 3.4 percent), and miscellaneous (3-13 percent, average 7.6 percent).

The significant percentages of volcanic lithologies in the study area are much different than in alluvial fans west of the Tok fan in the Tanana River valley and apparently represent an influx of sediment from volcanic terranes south of the Denali fault (Richter, 1976). Fernald (1965) attributed the source of volcanic erratics in the upper Tanana River drainage to the Nabesna River, a tributary of the Tanana River that drains the Wrangell Mountains. However, we traced vesicular volcanic pebbles and cobbles in gravels for several miles up the Tok River, Little Tok River, and Station Creek valleys away from the Tanana River, and believe that glaciers from the Wrangell Mountains transported volcanic clasts into the headwaters of the Tok River, where they were retransported during several glacial outburst floods as suggested by Schmoll (1984) (fig. 2). Along the Tanana River, mapping east of the Tok fan failed to identify outburst flood deposits.

\section{MATERIAL SITE (M.S.) 62-2-005-2}

Particularly instructive gravel exposures were discovered in Material Site 62-2-005-2 in an isolated remnant of the older, higher fan surface east of the Tok River (fig. 2, locality A). A 6-ft (1.8-m) greenstone boulder is exposed in place in clast- and matrix-supported gravels in the south pit wall (fig. 4). The bottom of the boulder is $7.9 \mathrm{ft}(2.4 \mathrm{~m})$ below the top of the gravel section in this wall. Near the center of the gravel pit, a pile of six very large boulders of granite, quartz schist, greenstone, and basalt, ranging in maximum diameter from 3.6 to $6.3 \mathrm{ft}$ (1.1 to $1.9 \mathrm{~m}$ ), provides evidence that several of these extraordinarily large rocks were encountered during pit excavation. The large in situ boulder rests in the upper part of a clean, clast-supported pebble gravel deposit with numerous subrounded to rounded polymictic cobbles and a slight pebble imbrication that indicates flow from the head of the Tok fan. Particularly noteworthy is the presence of a 4.3-in-thick (11-cm-thick) zone of disturbance beneath the boulder, perhaps indicating that the underlying material was deformed when the boulder was deposited. In this zone, pebbles are generally oriented parallel to the boulder surface; otherwise, the clast-supported gravel appears massive.

Figure 3. Soil profile (SP-11) exposed in west wall of M.S. 62-2-0095 in western Tok fan, in west-central Tanacross B-5 Quadrangle. Elevation 1,554 ft (471 m). 
The large boulder and the clast-supported gravel are abruptly overlain by matrix-supported massive pebble gravel with scattered small cobbles (fig. 4). Sieve analyses of samples S-9 and S-10 from this unit indicate that the fine fraction represents 5.4 and 2.8 weight percent, the sand fraction represents 12 and 14 weight percent, and the mean grain size is 0.86 and $0.81 \mathrm{in}$. (21.72 and $20.50 \mathrm{~mm}$ ), respectively (table 1 ). Beneath the fill at the top of the wall, a layer of loess $\sim 1.6 \mathrm{ft}(\sim 0.5 \mathrm{~m})$ thick displays a post-Donnelly soil and is thought to be late Donnelly (MIS2) in age.

Inspection of the nearby pit walls indicates that the interbedded gravel and pebbly sand beds are generally massive, less than $3.3 \mathrm{ft}(1 \mathrm{~m})$ thick, tabular, have abrupt lower and upper

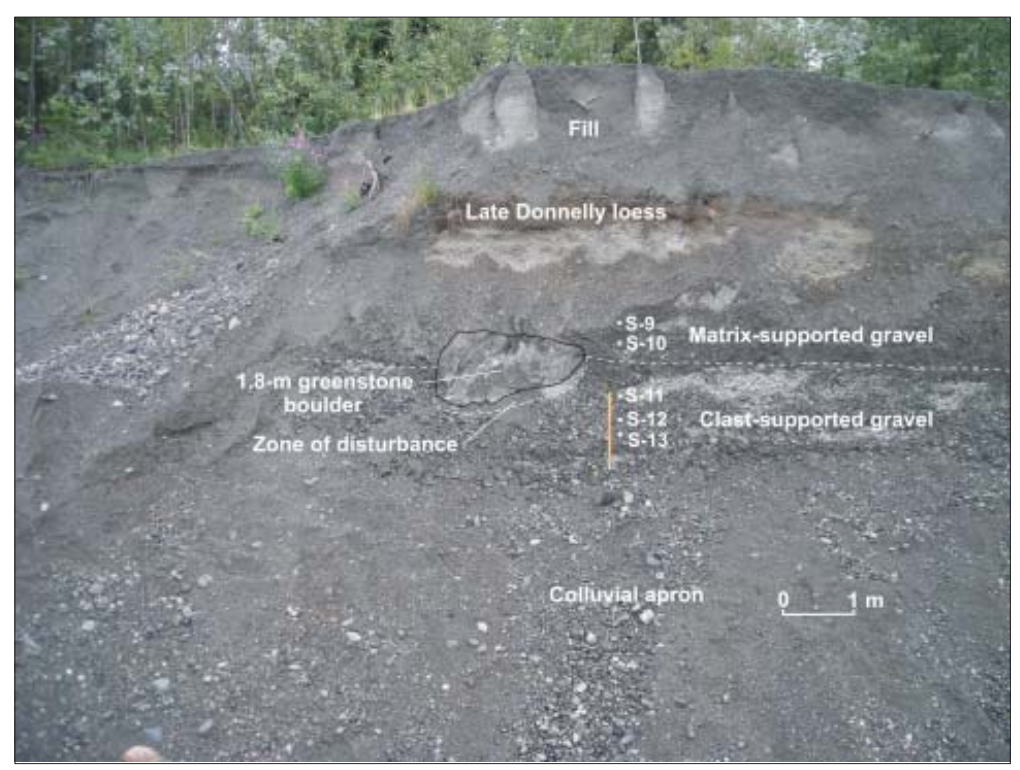

contacts, and parallel the fan surface. No cross bedding is present; however, two channel fills were identified, including a 20-in-thick (50-cm-thick) lens-shaped filling of massive sand in the south wall and a 3.3-ft-thick ( 1-m-thick) channel fill of massive sand overlying clast-supported gravel in the west wall of the pit (fig. 5). Eight samples of clast- and matrix-supported gravels and pebbly sand (S-1 through S-8) were collected from the west wall of M.S. 62-2-005-2 and analyzed for grain-size distribution (fig. 6, table 1). Particularly noteworthy, although not understood, is the ubiquitous presence of vertically oriented pebbles in matrix-supported gravels at the top of the section.

Other extraordinarily large boulders were discovered at localities B and C (fig. 2). However, nowhere else in the Tok fan have these exceptionally large boulders been recovered, even in gravel pits as deep as $35 \mathrm{ft}(10.6 \mathrm{~m})$ (Glenn Burnham, 08/05/08, oral commun.), and none were present in the several deep pits we inspected.

Carter and Galloway (1978) apparently saw some of these large boulders, although likely not in place, and mapped the isolated terrace remnant as old glacial moraine (Qmo), which they correlated with moraines of the Delta glaciation (MIS 4 and 6) to the west. Foster (1970) concluded that the terrace and the older part of the Tok fan west of the Tok River are genetically related and assigned both a Delta age.

Figure 4. Extraordinarily large in situ greenstone boulder outlined for clarity in clast- and matrix-supported gravels and sample locations in south wall of M.S. 62-2-005-2, northeastern Tok fan, Tanacross B-4 Quadrangle (locality A). Photograph taken 07/29/08 by R.D. Reger.

Table 1. Grain-size distributions of gravels and sands exposed in west wall (samples S-1 through S-8) and south wall (samples S-9 through S-13) of M.S. 62-2-005-2 (locality A), Tanacross B-4 Quadrangle (figs. 4 and 6).

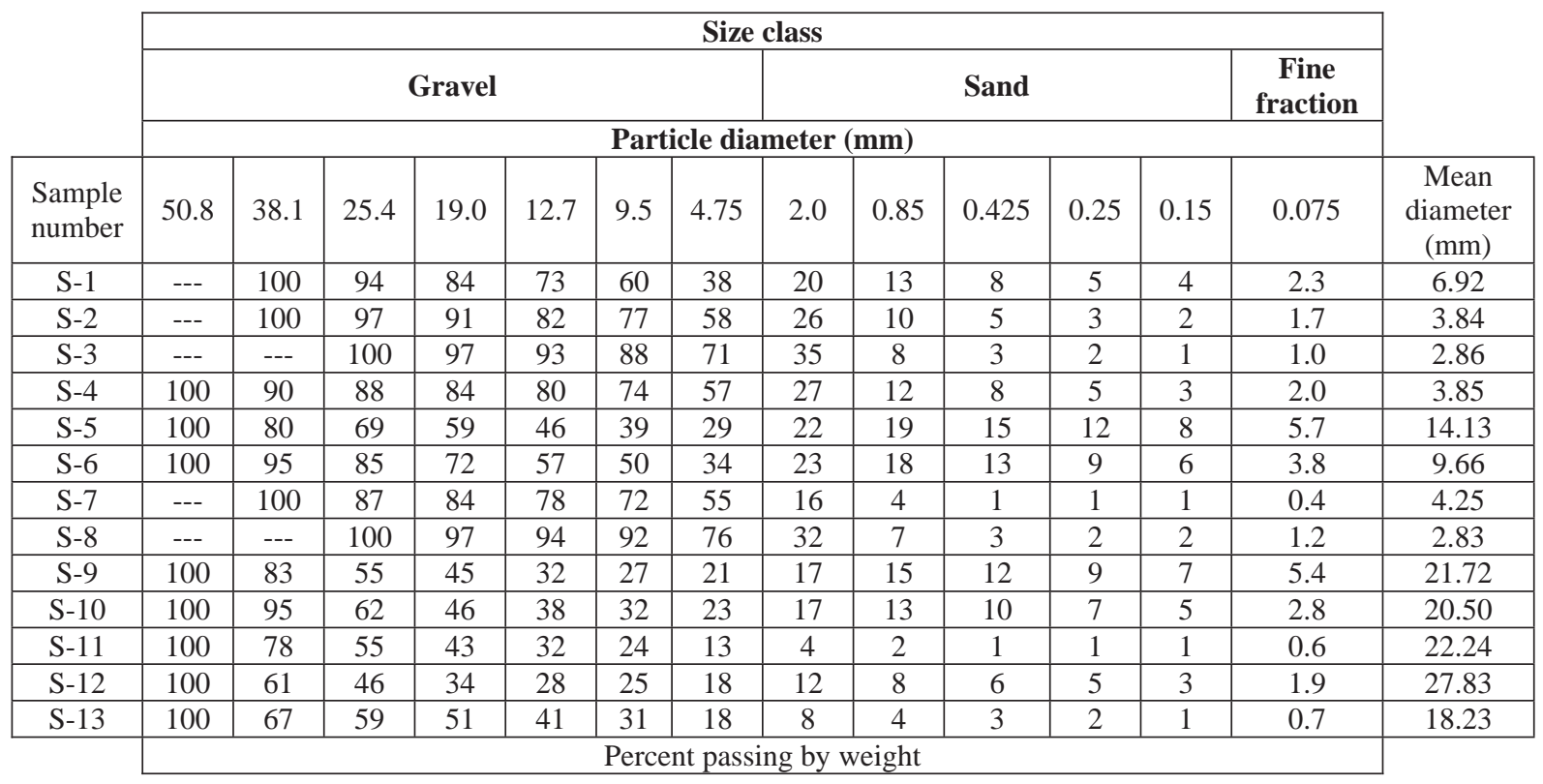



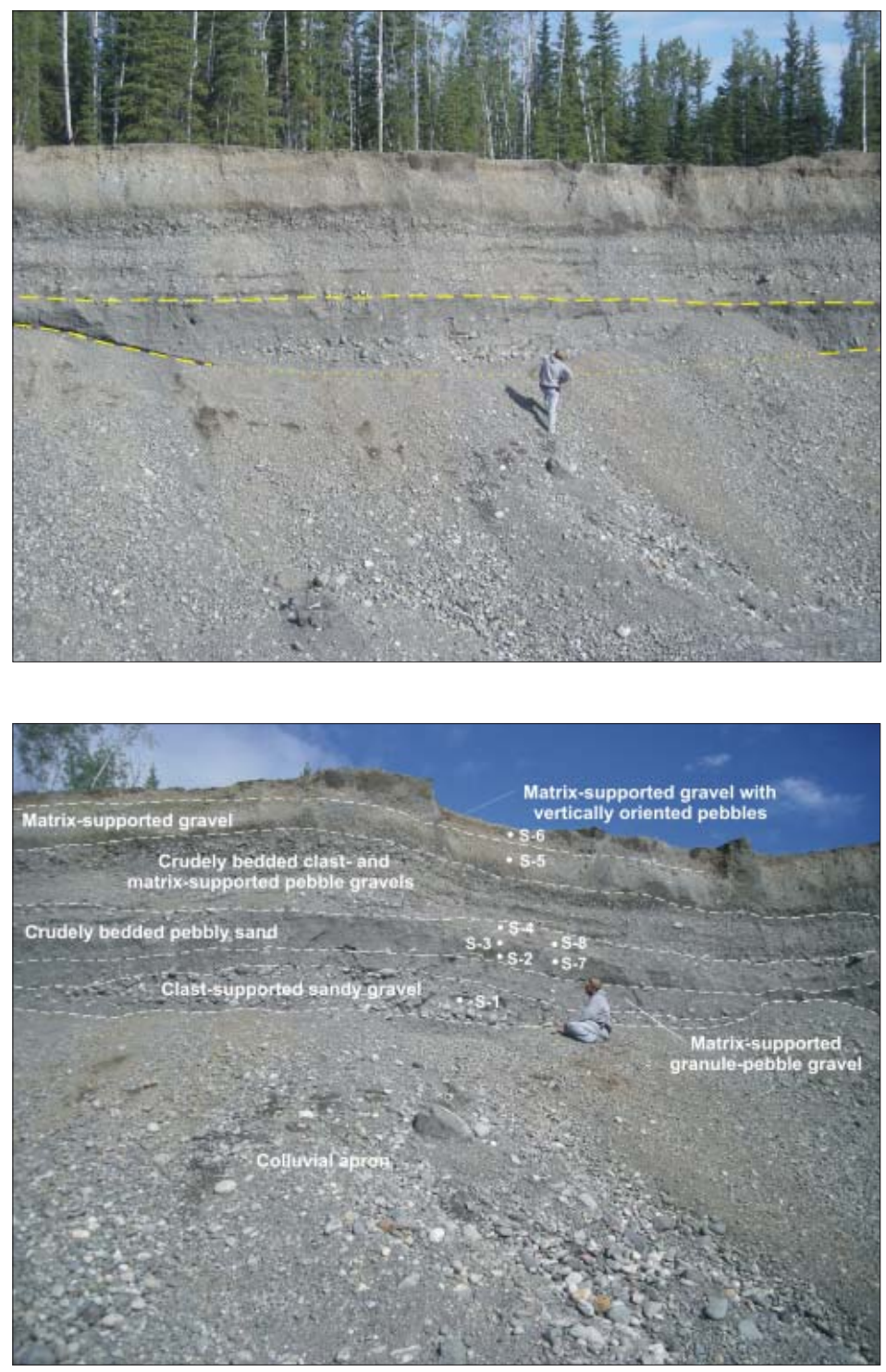

Carrara (2006) recognized that both surfaces are equivalent and dated them as middle Pleistocene. Based on the presence of post-Donnelly soil profiles and the generally thin cover of loess, we believe that the older part of the Tok fan surface is Donnelly (MIS 2) in age.

\section{DISCUSSION}

The lack of glacial till in any of the water wells or gravel-pit exposures in the Tok fan indicates that the extraordinarily large boulders were not deposited directly from glacial ice as inferred by Carter and Galloway (1978). The absence of stratigraphic features normally deposited by water floods, including cutand-fill structures, ripples, and cross bedding, indicates that the boulders were not deposited by typical water floods. We propose that the very large boulder in the near-surface, tabular, clast- and matrix-supported gravels and pebbly sands in M.S. 62-2-005-2 is evidence that the extraordinarily large, rare boulders were deposited as dropstones from icebergs during massive outburst floods flowing north through the Tok River valley and spreading as waves (sheetflows) across the shallow fan surface. We speculate that these large boulders were initially dumped near
Figure 5. Cross section through large channel filling in west wall of M.S. 62-2-005-2, northeastern Tok fan, Tanacross $B$-4 Quadrangle (locality A). Contact dotted where inferred beneath colluvial apron. Geologist provides scale. Photo taken $08 / 01 / 08$ by R.D. Reger.

Figure 6. Locations of samples in exposed gravels and sands in west wall of M.S. 62-2-005-2, northeastern Tok fan, Tanacross B-4 Quadrangle (locality A). Photograph taken 08/01/08 by R.D. Reger.

the sites of their ultimate burial and then may have been rolled across the fan surface a very short distance before quickly being buried by subsequent flood pulses. Large boulders carried or moved by the flood have been found in the Tok fan only in line with the trend of the Tok River valley, indicating that the focus of the boulder-bearing outburst floods was in that direction (fig. 2, localities B-C). However, through time gravel-bearing flows must have traversed the fan and deposited the thick gravel layers observed.

The interlayered nature of the tabular gravels and sands enclosing the large flood boulder in M.S. 62-2-005-2 and the clear difference in their compositions (fig. 7 and table 1) indicate that the large-magnitude flows pulsated during the outburst flooding, probably as a result of temporary blockages of subglacial drainageways through which floodwaters bypassed the glacier dam (Sturm and others, 1987; Sturm and Benson, 1989; Tweed and Russell, 1999). We suggest that gravel-rich beds represent bedload components deposited by water-dominated flood pulses and that pebbly sands and matrix-supported gravels preserve components of the suspended load that were deposited by watery hyperconcentrated flows. The older part of the Tok fan has morphological characteristics, such as a broad, low gradient, low relief, and a surface network of shallow distributary channels, of a fan dominated by sheetflooding (Blair and McPherson, 1994, fig. 1B).

These massive floods had to occur many times to deliver the huge volume of coarse deposits present in the Tok fan. Inspections of several deep gravel pits indicate that at least the upper $35 \mathrm{ft}(10.6 \mathrm{~m})$ of fan sediments accumulated without a significant hiatus during the Donnelly glaciation. Deeper sediments in the Tok fan were likely laid down by pre-Donnelly outburst floods. 


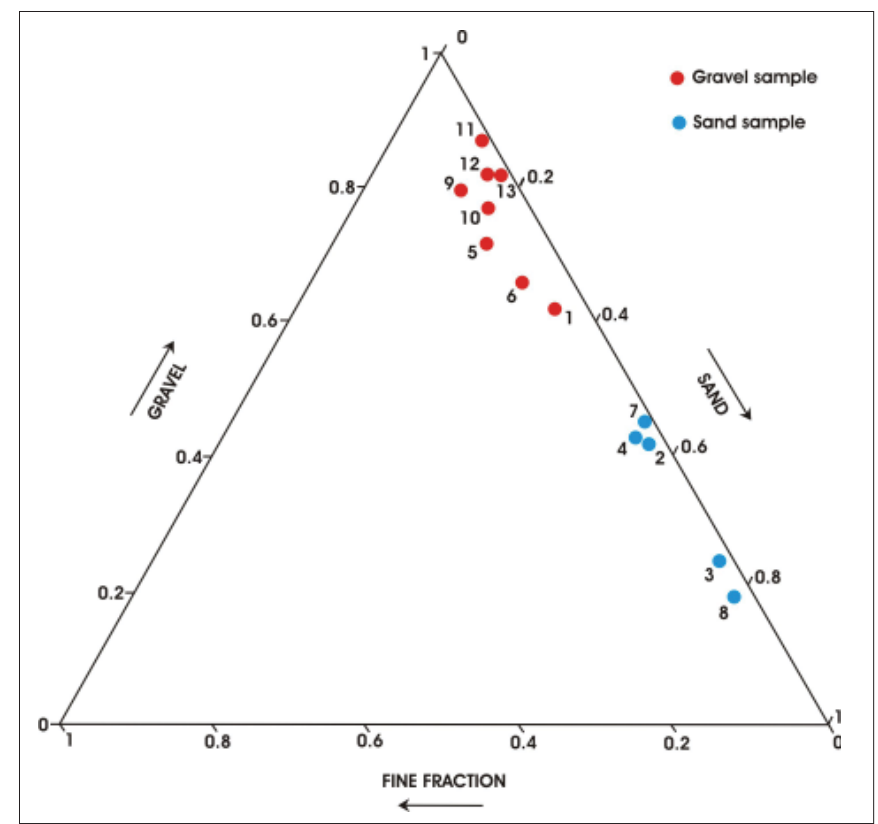

Figure 7. Abundances of gravel, sand, and fine-fraction components in samples of gravel and sand beds in south and west walls of M.S. 62-2-005-2 (table 3), northeastern Tok fan, Tanacross B-4 Quadrangle (locality A).

\section{REFERENCES}

Blair, T.C., and McPherson, J.G., 1994, Alluvial fans and their natural distinction from rivers based on morphology, hydraulic processes, sedimentary processes, and facies assemblages: Journal of Sedimentary Research, v. A64, no. 3, p. 450-489.

Carrara, P.E., 2006, Surficial geologic map of the Tanacross B-4 Quadrangle, east-central Alaska: U.S. Geological Survey Scientific Investigations Map 2935, version 1.0, 1 plate, scale 1:63,360.

Carter, L.D., and Galloway, J.P., 1978, Preliminary engineering geologic maps of the proposed natural gas pipeline route in the Tanana
River valley, Alaska: U.S. Geological Survey Open-file Report 78-794, 26 p., 3 plates, scale 1:125,000.

Combellick, R.A., 2006, Building a natural gas pipeline through earthquake country: Geotimes, v. 51, no. 11, p. 18-22.

Fernald, A.T., 1965, Glaciation in the Nabesna River area, upper Tanana River valley, Alaska, in U.S. Geological Survey Research 1965: U.S. Geological Survey Professional Paper 525-C, p. C120-C123.

Foster, H.L., 1970, Reconnaissance geologic map of the Tanacross Quadrangle, Alaska: U.S. Geological Survey Miscellaneous Geologic Investigations Map I-593, 1 plate, scale 1:250,000.

Holmes, G.W., 1965, Geologic reconnaissance along the Alaska Highway, Delta River to Tok Junction, Alaska: U.S. Geological Survey Bulletin 1181-H, 19 p., 1 plate, scale 1:125,000.

Richter, D.H., 1976, Geologic map of the Nabesna Quadrangle, Alaska: U.S. Geological Survey Miscellaneous Investigations Map I-932, 1 plate, scale 1:250,000.

Schmoll, H.R., 1984, Late Pleistocene morainal and glaciolacustrine geology in the upper Copper River-Mentasta Pass area, Alaska [abs.]: Geological Society of America Abstracts with Programs, v. 16 , no. 6 , p. 330 .

Solie, D.N., and Burns, L.E., 2007, Alaska Highway corridor geology and geophysics: Alaska GeoSurvey News, v. 10, no. 1, p. 1-4.

Sturm, Matthew, and Benson, C.S., 1989, Jökulhlaups from Strandline Lake, Alaska, with special attention to the 1982 event: Alaska Division of Geological \& Geophysical Surveys Report of Investigations 88-10, 19 p.

Sturm, Matthew, Begét, J.E., and Benson, C.S., 1987, Observations of jökulhlaups from ice-dammed Strandline Lake, Alaska: Implications for paleohydrology, in Mayer, L., and Nash, D., eds., Catastrophic flooding: Boston, Allen and Unwin, Binghamton Symposia in Geomorphology, International Series, v. 18, p. 79-94.

Tweed, F.S., and Russell, A.J., 1999, Controls on the formation and sudden drainage of glacier-impounded lakes; Implications for jökulhlaup characteristics: Progress in Physical Geography, v. 23, no. 1, p. 79-110.

Williams, J.R., 1970, Ground water in the permafrost regions of Alaska: U.S. Geological Survey Professional Paper 696, 83 p.

\section{NEW DGGS PUBLICATIONS}

\section{ANNUAL REPORTS}

AR 2009. Alaska Division of Geological \& Geophysical Surveys Annual Report, by DGGS Staff, 2010, 76 p. Free

\section{GEOLOGIC MATERIALS CENTER REPORTS}

GMC 358. Original geologic core logs, sample records and corresponding assay logs for the Arctic Prospect of Northern Alaska; holes no. DH-1, DH-2, DH-3, DH-4, DH-5, DH-7 and DH-8, by Sperry-Sun Drilling Services, 2009, 97 p. Free

GMC 359. Geochemical analysis of core from the U. S. Navy Gubik TestWell No. 1 (3,491.5', 3,492', 3,577' and 3,599') and U. S. Navy Gubik Test Well No. 2 (1,849.7', 1,852.5', 1,856.5', 1,863' and 1,868'), by ConocoPhillips, 2009, 5 p. Raw data provided in excel table. Chromatograms included in PDF document. Additional data is available on DVD upon request. Free
GMC 360. Photomicrographs of Petrographic Thin Sections for the Inigok \#1, Peard Test Well \#1, and Prudhoe Bay State \#1 wells., by Shell International EP, Inc., 2009, 11 p., 1 disk. Additional data in TIFF format available on DVD. Free

GMC 361. X-ray Diffraction Analysis of: Drew Point \#1, East Simpson Test Well \#1, East Simpson \#2, Ikpikpuk \#1, Seabee \#1, W. Dease \#1 wells, by Talisman Energy Inc., and Core Laboratories, 2009, 17 p. Free

GMC 362. QFT (Fluorescence) Characterization for Inigok \#1, Milne Pt Unit KR \#A-01, Itkillik Unit \#1 wells, by Talisman Energy Inc., and Core Laboratories, 2009, 14 p. Free

GMC 363. Petrographic Analysis of Samples from 9 NPRA Wells, North Slope, Alaska: East Simpson \#2, West Dease \#1, J.W. Dalton \#1, East Simpson \#1, Seabee \#1, Drew Pt. \#1, Topagoruk Test \#1, South Meade \#1, Ikpikpuk \#1, by FEX L.P., 2009, 33 p. Excel files of grain size data and point count data available. Free 
GMC 364. Advanced Rock Properties Study on Core samples from 8 wells in Alaska: Drew Pt \#1, East Simpson Test Well \#1, East Simpson \#2, Ikpikpuk \#1, J.W. Dalton \#1, Seabee \#1, Topogoruk Test \#1, and W. Dease \#1, by Talisman Energy Inc., and Core Laboratories, 2009, 154 p. Free

GMC 365. Hydrocarbon Extracts From Core Chip Samples: Ivishak Unit \#1, Susie \#1, Gubik Test \#2, Square Lake Test Well \#1, by FEX L.P., and Weatherford Laboratories, 2009, 299 p. Free

GMC 366. Makushin Geothermal Project ST-1 Core 2009 re-sampling and analysis: Analytical results for anomalous precious and base metals associated with geothermal systems, by Alaska Earth Sciences, 2009, 1 p. Free

GMC 367. Sidewall core analyses from 32 Alaska OCS wells, by Minerals Management Service, and Core Laboratories, 2009, 3 p., 1 disk. Additional data on DVD available upon request. Free

GMC 368. Geochemical analysis (total organic carbon, rockeval, bitumen geochemistry, vitrinite reflectance) from the Ikpikpuk \#1, W.T. Foran \#1, J.W. Dalton \#1, Seabee \#1, Sentinel Hill, Titaluk Test \#1, N. Inigok \#1, Drew Pt. \#1, Gubik Test \#1, Inigok \#1 and Oumalik Test \#1 wells, by Petro-Canada Oil and Gas, and JP Petrographics, 2009, 1 p. Free

\section{GEOPHYSICAL MAPS \& REPORTS}

GPR 2009-1. Line, grid, and vector data, and maps for the airborne geophysical survey of the Slate Creek-Slana River Survey, Chistochina mining district, south-central Alaska, by Burns, L.E., Fugro Airborne Surveys Corp., and Stevens Exploration Management Corp., 2009, 18 sheets, scale 1:63,360, 1 disk. 1 database, 6 grids, and 6 vector files available on DVD for $\$ 10$. 18 sheets in all, individual sheets available for $\$ 13$ each.

\section{GUIDEBOOKS}

GB 9. Dalton Highway Field Trip Guide for the Ninth International Conference on Permafrost, by Walker, D.A., Hamilton, T.D., Ping, C.L., Daanen, R.P., and Streever, W.W., 2009, 104 p. A supplement to Guidebook 4, “Guidebook to permafrost and related features along the Elliott and Dalton Highways, Fox to Prudhoe Bay, Alaska,” 1983, by Jerry Brown and R.A. Kreig, editors, published by the Alaska Division of Geological \& Geophysical Surveys for the Fourth International Conference on Permafrost. \$15

\section{INFORMATION CIRCULARS}

IC 58. Alaska’s mineral industry 2008: A summary, by Szumigala, D.J., Hughes, R.A., and Harbo, L.A., 2009, 15 p. Free

IC 59. Historically active volcanoes of Alaska reference deck, by Snedigar, S.F., and Cameron, C.C., 2009, 52 p. \$6
(1)

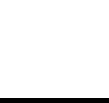

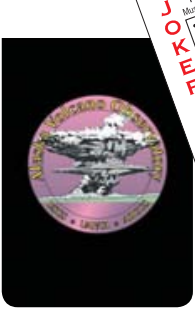

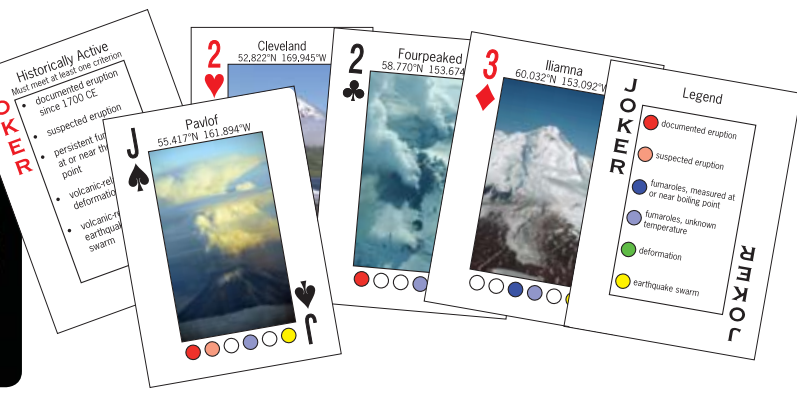

IC 59 is a unique publication as it is in the format of playing cards. We think it's no coincidence that there are exactly 52 historically volcanoes in Alaska as of December 2009; and we hope to engage the user in a fun, educational experience. Each full-color card provides the location coordinates and photo of the volcano, and up to six colored dots that correspond to a legend on one of the joker cards. The dots represent characteristics of the volcano, such as a documented eruption, fumaroles, deformation, or earthquake swarms. The packet includes a two-sided information sheet with photo captions/credits for each volcano. \$6
Progress during the 2006-2007 field season, by LePain, D.L., 2009, 187 p. \$19
MP 133. Historically active volcanoes of Alaska, by Schaefer, J.R., Cameron, C.E., and Nye, C.J., 2009, 1 sheet, scale $1: 3,000,000 . \$ 13$

\section{NEWSLETTER (ALASKA GEOSURVEY NEWS)}

NL 2009-1. The Alaska Geologic Materials Center, by Reeder, PRELIMINARY INTERPRETIVE REPORTS

PIR 2009-6c. Reconnaissance interpretation of 1978-1983 permafrost, Alaska Highway Corridor, Robertson River to Tetlin Junction, Alaska, by Reger, R.D. and Hubbard, T.D., 2010, 13 p., 4 sheets, scale 1:63,360. \$54

PIR 2009-3. A reconnaissance view of an unnamed fault near Capps Glacier, northwestern Cook Inlet basin, and its potential as a regional-scale, basin-controlling structure, by Gillis, R.J., LePain, D.L., Ridgway, K.D., and Finzel, E.S., 2009, 9 p. \$2

and provenance of Cenozoic strata, Chuitna and Beluga rivers area, Cook Inlet forearc basin, Alaska, by Finzel, E.S., Gillis, R.J., Ridgway, K.D., and LePain, D.L., 2009, 16 p. \$2 area, east-central Brooks Range Foothills, Alaska, by Mull, C.G., Harris, E.E., Delaney, P.R., and Swenson, R.F., 2009, 40 p., 1 sheet, scale 1:63,360. \$17

Lake Quadrangle, Alaska, by Harris, E.E., Delaney, P.R., Mull, C.G., LePain, D.L., and Burns, P.C., 2009, 1 sheet, scale 1:63,360. \$13

PIR 2009-8. Preliminary results of recent geologic investigations in the Homer-Kachemak Bay area, Cook Inlet Basin: 
PIR 2009-8A. Facies associations, sand body geometry, and depositional systems in Late Oligocene-Pliocene Strata, southern Kenai Peninsula, Cook Inlet, Alaska: Report on progress during the 2006-07 field season, by LePain, D.L., Wartes, M.A., McCarthy, P.J., Stanley, R.G., Silliphant, L.J., Peterson, Shaun, Shellenbaum, D.P., Helmold, K.P., Decker, P.L., Mongrain, Jacob, and Gillis, R.J.

PIR 2009-8B. Sedimentology of an Oligocene-Miocene incised paleovalley, Tyonek Formation, Cook Inlet Basin, Alaska, by Finzel, E.S., Ridgway, K.D., and LePain, D.L.

PIR 2009-8C. Report on day trip (5/16/07) to visit Mesozoic rocks exposed in Port Graham and near Seldovia, southern Kenai Peninsula, by Blodgett, R.B.

PIR 2009-8D. Mercury injection capillary pressure results from outcrop samples in the Homer area of Cook Inlet, by Loveland, Andrea.

\section{RAW-DATA FILES}

RDF 2009-1. Geochemical, major-oxide, minor-oxide, traceelement and carbon data from rocks collected in 2008 in the eastern Bonnifield mining district, Fairbanks and Healy quadrangles, Alaska, by Freeman, L.K., Werdon, M.B., Szumigala, D.J., Andrew, J.E., Newberry, R.J., and Athey, J.E., 2009, 69 p. \$7
RDF 2010-1. Results of mercury-injection capillary pressure tests on outrcrop samples in the Tyonek area of Cook Inlet, by Andrea M. Loveland, 2010, 102 p. \$10

\section{REPORTS OF INVESTIGATIONS}

RI 2009-1. Sedimentology and sequence stratigraphy of the middle Albian-Cenomanian Nanushuk Formation in outcrop, Central North Slope, Alaska, by LePain, D.L., McCarthy, P.J., and Kirkham, Russell, 2009, 78 p., 1 sheet. \$21

RI 2009-2. Chert geochemistry discriminant analysis and K-means cluster analysis: Rampart project area, Tanana B-1 Quadrangle, east-central Alaska, by Reifenstuhl, R.R., Newberry, R.J., Haug, S.A., Clautice, K.H., Liss, S.A., and Weber, F.R., 2009, 16 p. \$2

RI 2009-3. Surficial-geologic map of the Kavik River area, west-central Mount Michelson Quadrangle, northeastern Brooks Range, Alaska, by Carson, E.C., 2009, 1 sheet, scale 1:63,360. \$13

\section{SPECIAL REPORTS}

SR 63. Alaska's mineral industry 2008, by Szumigala, D.J., Hughes, R.A., and Harbo, L.A., 2009, 89 p. Free

\section{ORDERING INFORMATION}

For each publication ordered, include both the publication title and number. Mail orders are payable in advance. Make check or money order in U.S. currency and payable to the State of Alaska. Credit cards are accepted. Telephone orders are accepted by the Fairbanks office between 8 a.m. and 5 p.m. Alaska time. Fax and email requests are accepted any time; these orders will be invoiced. If you would like to leave your order on voice mail, this can also be done 24 hours a day and you will be invoiced.

\section{SHIPPING \& HANDLING}

Shipping charge will be the actual cost of postage and will be added to the total amount due. Please e-mail or call for an exact amount.

\section{WHERE TO ORDER}

Publications of the Division of Geological \& Geophysical Surveys are available over the counter, by mail, phone, fax, or email from the DGGS Fairbanks office:

ATTN: Geologic Communications Section-Publication Sales Alaska Division of Geological \& Geophysical Surveys, 3354 College Rd. Fairbanks, AK 99709-3703 (907) 451-5020 Fax (907) 451-5050 Email: dggspubs@alaska.gov

Prices of DGGS publications are subject to change. Increases in costs make it necessary to raise the selling prices of many publications offered. It is not feasible for DGGS to change the prices stated in previous announcements and publications in stock, so the prices charged may differ from the prices in the announcements and publications. Overpayments of \$2 or less will not be refunded.

\begin{tabular}{|c|}
\hline Please send address corrections to: \\
Newsletter, Alaska Division of Geological \& Geophysical Surveys \\
3354 College Rd., Fairbanks, AK 99709-3707 \\
(907) 451-5020 (907)451-5050 fax \\
email: dggsnews@alaska.gov \\
http://www.dggs.dnr.state.ak.us \\
\hline
\end{tabular}

\section{Visit our web page at http://www.dggs.dnr.state.ak.us}




\section{Dear Readers:}

In this issue of Alaska GeoSurvey News, geologists Trent Hubbard and Richard Reger report on one of the many interesting scientific outcomes from DGGS's field work along the proposed natural-gas pipeline corridor between Delta Junction and the Canada border. Their observations tell the fascinating story of multiple catastrophic glacial outburst floods that occurred in the ancestral Tok River valley during the last major glaciation. This story explains the morphology of the broad Tok fan and the presence of huge ice-rafted boulders in those gravelly deposits.

DGGS conducted its last full field season of geologic mapping and hazards evaluation along this corridor in 2009. Although there will likely be some follow-up fieldwork in 2010, our focus will shift to synthesis of all the data we've collected and preparation of final reports and maps, which will probably be ready for release in late 2011 or early 2012. DGGS initiated this effort in 2006 to evaluate the geologic hazards and resources along the Alaska Highway. This information will be useful not only for possible pipeline construction, but also for other potential future commercial and residential development along this important corridor. We no longer need to worry about catastrophic glacial outburst floods in this area, but the knowledge of these and other geologic processes helps us understand the characteristics and distribution of deposits that can serve as important sources of construction materials, as well as other potential hazards and engineering constraints.

Several significant staff changes have occurred in DGGS during the past year. Geologist John Reeder retired in June after nearly 30 years of service to DGGS and the State, the last 22 of which were as Curator of the Geologic Materials Center in Eagle River. In the fall, geologist Rocky Reifenstuhl retired after nearly 27 years of service, most of which were in the Energy Resources section. We thank both John and Rocky for their dedicated, productive service to the division. We are pleased to welcome four new geologists to the fold, as well as one returning after a short stint with another state agency. Trystan Herriott joins the Energy Resources section, Richard Koehler and Gabriel Wolken join the Engineering Geology section, Brent Elliott joins the Mineral Resources section, and returning geologist Ken Papp takes over as the new Curator of the GMC.

Finally, what about Bob? Not one to shy away from a challenge when he believes he can make a positive impact, State Geologist Bob Swenson responded to a call from Governor Sean Parnell for a temporary assignment to coordinate efforts to facilitate delivery of affordable natural gas to in-state customers. In this capacity, Bob is working closely with the Alaska Natural Gas Development Authority and former Division of Oil \& Gas and U.S. Geological Survey director Mark Myers, who is coordinating development of a large-diameter pipeline to export North Slope natural gas to markets in North America and elsewhere. Bob agreed to accept this assignment on a temporary basis until October 2010, when he expects to put his DGGS hat back on and return full time to his position as state geologist. In the meantime, I am honored to again serve as acting director.

You can read more about the backgrounds of these employees as well as all of DGGS's projects in our recently released annual report. It is available either in hard copy or online at www.dggs.dnr.state.ak.us. I invite you to stop by our office or call at any time if there is any project you would like to learn more about.

Sincerely,

\section{Rodney A Combellich}

Rodney A. Combellick

Acting Director 


\section{STATE OF ALASKA \\ DEPARTMENT OF NATURAL RESOURCES \\ DIVISION OF GEOLOGICAL \& GEOPHYSICAL SURVEYS}

Mail order to:

Alaska Division of Geological \& Geophysical Surveys

Attn: Geologic Communications Section 3354 College Rd.

Fairbanks, Alaska 99709-3707
E-mail: dggspubs@alaska.gov http://www.dggs.dnr.state.ak.us (907) 451-5020

Fax: (907) 451-5050

\begin{tabular}{|c|c|c|c|}
\hline Report Number & Report Name & Quantity & Price \\
\hline & & & \\
\hline & & & \\
\hline & & & \\
\hline & & & \\
\hline & & & \\
\hline & & & \\
\hline & & & \\
\hline & & & \\
\hline & & & \\
\hline & Total Publications & & \\
\hline & Shipping and Handling Charge & & \\
\hline & Total for all Publications and Shipping & & \\
\hline & Amount Paid & & \\
\hline & AMOUNT DUE & & \\
\hline
\end{tabular}

POSTAGE: Shipping charge will be the actual cost of postage and will be added to the total amount due. You may e-mail or call for an exact amount.

\section{Ship publication(s) to:}

Name

Organization

Address

City, State

Zip

Payment must accompany your order. Make check or money order payable to STATE OF ALASKA. 